Article

\title{
Silicon Supply Improves Leaf Gas Exchange, Antioxidant Defense System and Growth in Saccharum officinarum Responsive to Water Limitation
}

\author{
Krishan K. Verma ${ }^{1}$, Muhammad Anas ${ }^{1,2}$, Zhongliang Chen ${ }^{1,2}$, Vishnu D. Rajput ${ }^{3}{ }^{\mathbb{D}}$, \\ Mukesh Kumar Malviya ${ }^{1}$, Chhedi Lal Verma ${ }^{4}$, Rajesh Kumar Singh ${ }^{1} \mathbb{D}$, Pratiksha Singh ${ }^{1}{ }^{1}$, \\ Xiu-Peng Song ${ }^{1, *}$ and Yang-Rui Li $^{1, * \mathbb{D}}$ \\ 1 Key Laboratory of Sugarcane Biotechnology and Genetic Improvement (Guangxi), Ministry of Agriculture \\ and Rural Affairs/Guangxi Key Laboratory of Sugarcane Genetic Improvement/Sugarcane Research Institute, \\ Guangxi Academy of Agricultural Sciences, Nanning 530007, China; drvermakishan@gmail.com (K.K.V.); \\ anas.uaf@gmail.com (M.A.); czl_good2007@gxaas.net (Z.C.); malviyamm1983@gmail.com (M.K.M.); \\ rajeshsingh999@gmail.com (R.K.S.); singh.pratiksha23@gmail.com (P.S.) \\ 2 College of Agriculture, Guangxi University, Nanning 530004, China \\ 3 Academy of Biology and Biotechnology, Southern Federal University, 344006 Rostov-on-Don, Russia; \\ rajput.vishnu@gmail.com \\ 4 Irrigation and Drainage Engineering, ICAR-Central Soil Salinity Research Institute, Regional Research \\ Station, Lucknow 226005, India; lalcverma62@gmail.com \\ * $\quad$ Correspondence: xiupengsong@gxaas.net (X.-P.S.); liyr@gxaas.net (Y.-R.L.); Tel.: +86-18677128565 (X.-P.S.); \\ $+86-13807883389$ (Y.-R.L.)
}

Received: 13 July 2020; Accepted: 11 August 2020; Published: 14 August 2020

check for updates

\begin{abstract}
Silicon (Si) is not categorized as a biologically essential element for plants, yet a great number of scientific reports have shown its significant effects in various crop plants and environmental variables. Plant Si plays biologically active role in plant life cycle, and the significant impact depends on its bioaccumulation in plant tissues or parts. In particular, it has been investigated for its involvement in limited irrigation management. Therefore, this experiment was conducted to examine the effect of $\mathrm{Si}$ application in eco-physiological, enzymatic and non-enzymatic activities of sugarcane plants against water stress. Four irrigation levels, i.e., normal (100-95\% of soil moisture), 80-75, 55-50, and 35-30\% of soil moisture were treated for the sugarcane cultivar GT 42 plants supplied with 0, 100, 200, 300, 400 and $500 \mathrm{mg} \mathrm{Si} \mathrm{L}^{-1}$ and exposed for 60 days after Si application. Under stress, reduction in plant length $(\sim 26-67 \%)$, leaf area-expansion $(\sim 7-51 \%)$, relative water content $(\sim 18-57 \%)$, leaf greenness $(\sim 12-35 \%)$, photosynthetic pigments $(\sim 12-67 \%)$, physiological responses such as photosynthesis (22-63\%), stomatal conductance ( $25-61 \%)$, and transpiration rate ( $\sim 32-63 \%)$, and biomass production were observed in the plants without Si application. The drought condition also inhibited the activities of antioxidant enzymes like catalase ( 10-52\%), peroxidase (ca. 4-35), superoxide dismutase (10-44\%) and enhanced proline ( 73-410\%), and malondialdehyde content (ca. 15-158\%), respectively. However, addition of Si ameliorated drought induced damage in sugarcane plants. The findings suggest that the active involvement of $\mathrm{Si}$ in sugarcane responsive to water stress ranges from plant performance and physiological processes, to antioxidant defense systems.
\end{abstract}

Keywords: antioxidants; biomass; limited water; photosynthetic capacity; silicon; Saccharum spp. 


\section{Introduction}

As a result of rapid worldwide economic growth, limited irrigation is becoming an increasing, major environmental problem for plant growth and crop production. Plant water deficiency may result in scarcity of water supply in soil (water stress) or may create an interference to water uptake in plants [1,2]. The large areas of farming land are reported to suffer from seasonal water stress [3]. The global population has reached about 7.7 billion presently, which may further swell by up to ca. 2 billion in the coming 30 years, reaching approximately 10 billion by 2050 [4-6]. To feed such a large number of people would be a major challenge for agri-sectors, farmers and scientists against the dynamic era of climate change in near future [7]. The population ballooning may severely impair the land holding capacity, particularly in Asian countries [5]. The soil health may also be affected due to the enhanced use of the chemical fertilizers, insecticides and other contaminants such as plastics, arsenic, fluoride, salinity, GHGs and global warming [5], which would impair crop productivity, which is associated with the soil condition and other related environmental variables [8].

Agricultural land gets affected by salinity up to 1-2\% [9], while water stress accounts ca. $30 \%$ of the global land. Both stresses share many common similarities in terms of their impact on crop production [10]. The water stress in plants includes damage to the cell membrane functions and negative effects on photosynthetic capacity and antioxidative enzyme defense mechanisms [2,11,12]. Variations were noted in germination (\%) and root development, such as diameter, area expansion, total and main root growth. Some morphological changes, such as early leaf senescence, chlorosis, and necrosis, have been observed [5,11,12]. Drought damage can also be caused by the higher vapor pressure deficit in the environment, which results in more water loss via water vapor than the rate of water transport to the plant leaves [13]. In this situation, plant water status is disturbed, resulting in the disruption of metabolic functions and loss in growth and development [14]. Therefore, an essentiality appears to be to maintain and sustain the agriculture crop production against limited water availability, to continue to feed the growing population adequately.

Sugarcane (Saccharum officinarum L.) is a $\mathrm{C}_{4}$ crop mainly cultivated in arid and semi-arid areas throughout the world. The cultivation of Saccharum has been continuously enhanced and is considered as a renewable feedstock for valuable products such as sugar and bioethanol, and renewable energy sources to replace fossil fuels $[3,15,16]$. However, the remaining biomass after sugar and bioethanol production can be burned to generate renewable energy and/or used for 2G-bioethanol production $[17,18]$.

Silicon ( $\mathrm{Si}$ ) constitutes a crucial part of the soil in the form of silicate or aluminum silicates. Silicon serves as a biologically active and significant element for agriculture and is listed as 8th most common element in nature and the second most common element found in soil after molecular oxygen $[19,20]$. It is required for the growth of diatoms, sponge, and corals, and is also found to be associated with plant cell growth because $\mathrm{Si}$ enhances biotic resistance against bacteria, fungi, viruses, and herbivores [21-24]. Silicon is considered as quasi-essential [25] for plant development. Silicon is a high-quality fertilizer for developing economically sustainable agriculture. The impact of Si on plant growth, development and production has been well documented [26]. Silicon has been testified to gradually promote the development of biomass, productivity and quality of a wide latitude of crops such as monocots, dicots and some vegetables and fruit crops, which actively take up and accumulate excessive amount of Si by the plant parts [26]. Thus, Si exerts beneficial effects on plants' fitness and productivity by reducing environmental stresses $[2,11,12,27,28]$ along with regulation of defense signaling pathways.

However, knowledge about how Si modulates the morphological, physiological and biomass accumulation in Saccharum officinarum "GT 42" during water stress remains elusive. Although the essentiality of this element to plants is still debated, there have been significant impacts in our understanding of the uptake of $\mathrm{Si}$ in plants. In addition, present data regarding the precise amount of Si for its application method in Saccharum officinarum plants are limited. This study has examined the roles of $\mathrm{Si}$ on growth, photosynthetic capacity and antioxidative enzymes of sugarcane plants under 
combined irrigation with $\mathrm{Si}$ and limited water supply, in order to provide evidence demonstrating the biological and atmospheric responses of $\mathrm{Si}$ in increasing tolerance to abiotic stresses.

\section{Materials and Methods}

\subsection{Experimental Site and Treatment Design}

A pot experiment was conducted during the period March-September 2019 in a greenhouse at the Sugarcane Research Institute, Guangxi Academy of Agricultural Sciences, Nanning, Guangxi, China $\left(23.6^{\circ} \mathrm{N} 108.3^{\circ} \mathrm{E}\right)$. Sugarcane is widely cultivated in southern China, such as in the Guangxi, Yunnan, Guangdong and Hainan provinces. Sugarcane (Saccharum spp. cv. GT 42) culms were germinated inside the greenhouse in the field plot. Following standard agronomic practices, bud cane setts were planted in the month of March. Recommended row to row $(75 \mathrm{~cm})$ spacing was maintained. Basal nitrogen, phosphorus and potassium (NPK) doses were applied at the time of sowing. Before sowing, cane buds were dipped in water for up to $48 \mathrm{~h}$ and treated with Bavistin solution (fungicide) for $5 \mathrm{~min}$. Sixty-days after sowing, the plants were shifted into the plastic pots, filled with $3.5 \mathrm{~kg}$ soil pot $^{-1}$ (agricultural fertile soil and compost, 2:1, w/w) and kept in a greenhouse. The availability of macroand micro-nutrients in the filled soil was analyzed prior to the experiment (Supplementary Figure S1 and Table S1).

All the plants were irrigated every day up to soil moisture capacity to establish normal plant growth. The four levels of soil moisture were maintained as $100-95,80-75,55-50$ and $35-30 \%$ of field capacity up to sixty-days under limited water supply (Figure 1D). The soil moisture content was observed according to Verma et al. [2]. During the drying cycle, tillers were cut immediately after emergence. The experiment consisted of six silicon solutions with different $\mathrm{Si}$ levels such as 0 (control), $100,200,300,400$ and $500 \mathrm{mgl}^{-1}$. The Si solution was prepared by dissolving the appropriate quantities of $\mathrm{CaO} \cdot \mathrm{SiO}_{2}$, and applied twice with the irrigation at an interval of four weeks. This experiment was designed to be completely randomized with ten biological replicates.

During the experiment, minimal day-to-day changes in climatic variables such as diurnal average air temperature, air relative humidity and average light exposure were monitored (Figure 1A-C). Soil moisture (\%) in the Si applied plants was maintained to be equal to control plants. Soil moisture (\%) at 0-10 cm from soil depth was observed by Soil Moisture Meter at three points in each pot during the experiment (Figure 1D).
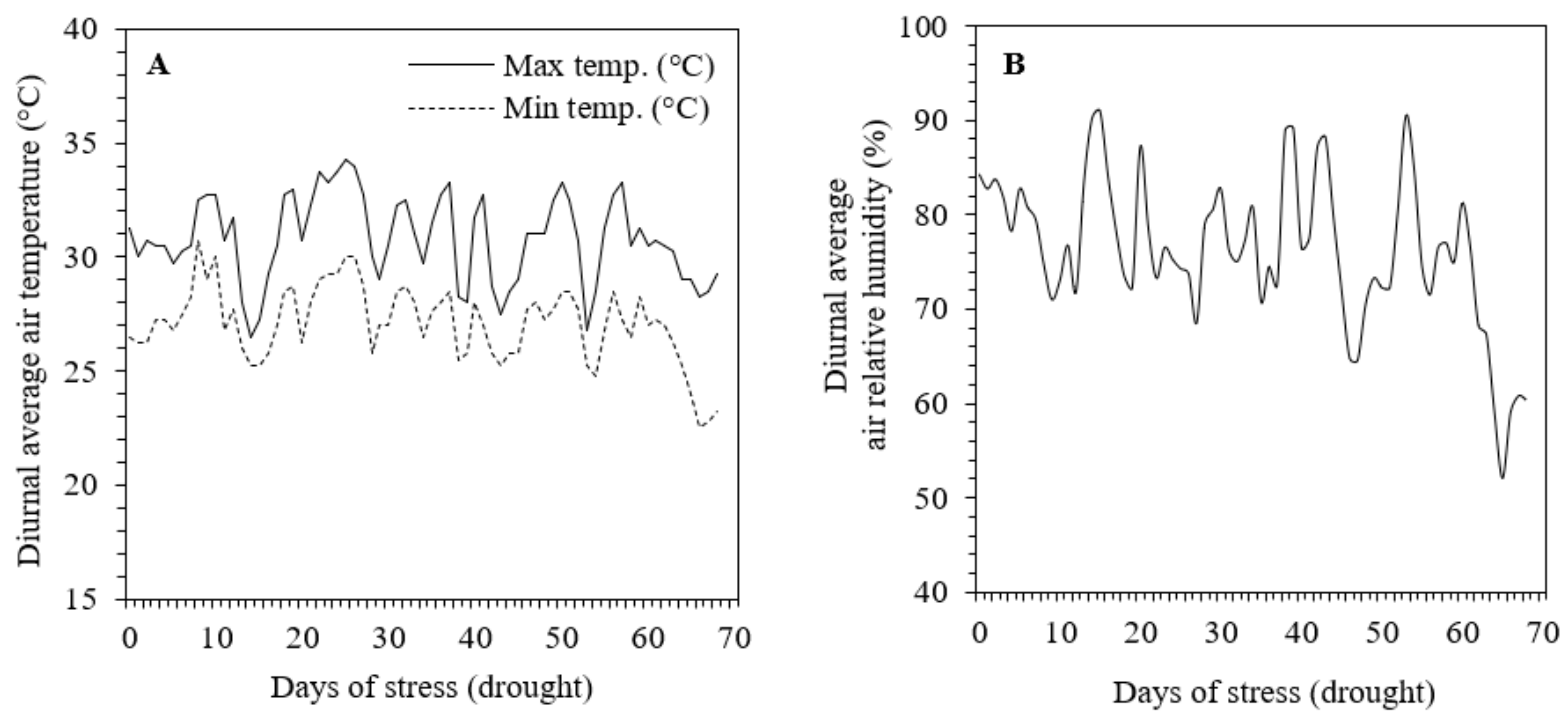

Figure 1. Cont. 

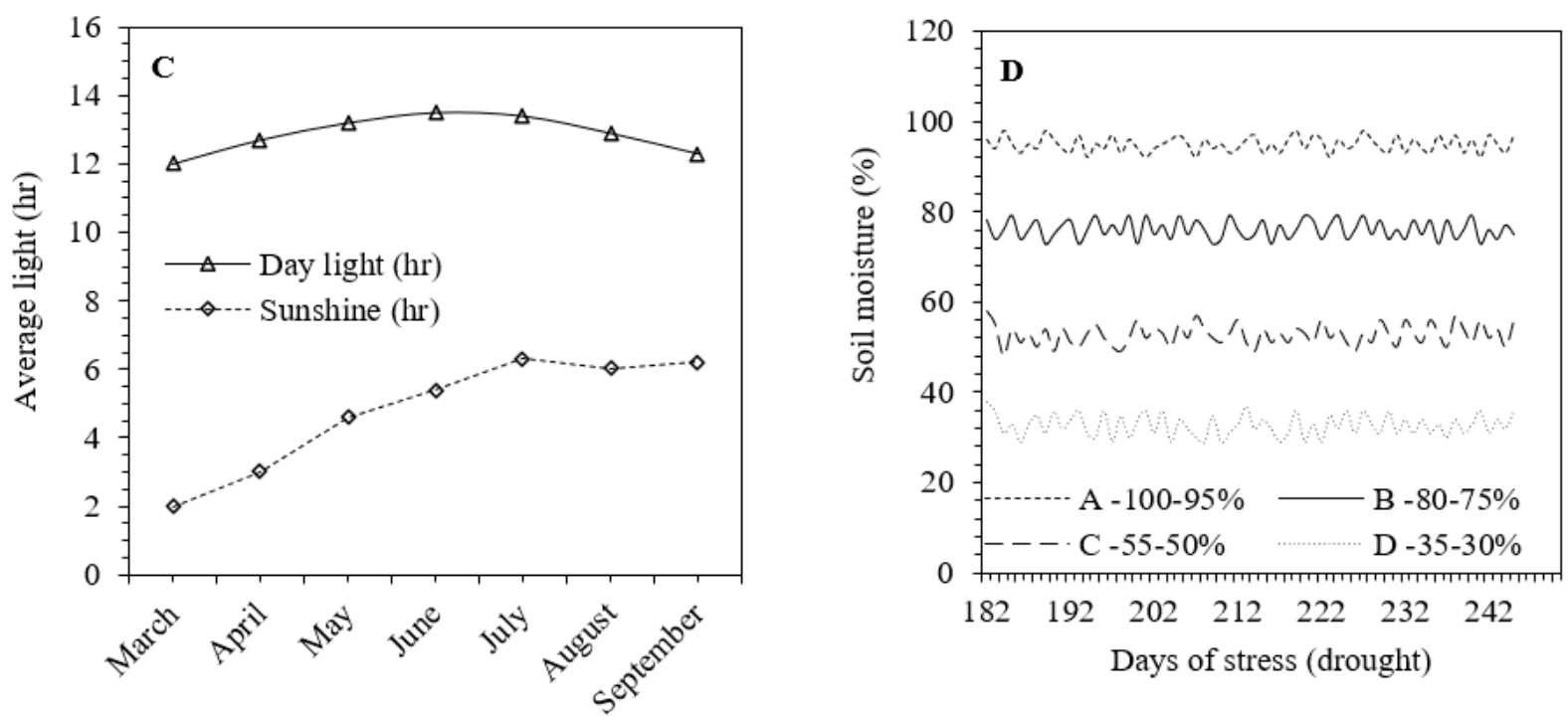

Month of year (2019)

Figure 1. (A) Diurnal variation in average temperature $\left({ }^{\circ} \mathrm{C}\right),(\mathbf{B})$ air relative humidity $(\%),(\mathbf{C})$ day light-sunshine (h) and (D) soil moisture (\%) during the experiment.

\subsection{Determination of Relative Water Content, Chlorophyll and Chlorophyll Stability Index}

Fresh, fully expanded top visible dewlap $($ TVD, leaf +1 ) leaves from randomly selected plants were used to determine the relative water content of leaf and photosynthetic pigments. The collected leaves were sealed in plastic bags and carried to the laboratory. After fresh weight measurement, leaves were immersed in tap water overnight in a refrigerator, placed over tissue paper for drying, and then weighted. Leaf samples were dried at $65^{\circ} \mathrm{C}$ in an oven, after which the dry mass was observed [29].

Photosynthetic pigments were estimated by dimethyl sulphoxide (DMSO) as the extraction reagent [30]. The absorbances at 663 and $645 \mathrm{~nm}$ were recorded by spectrophotometer, with DMSO being used as a blank. The relative leaf greenness was estimated using a Chlorophyll Meter (SPAD-502, Minolta, Inc. Japan) on the same leaves as the photosynthetic measurements with ten measurements per leaf per plant. The chlorophyll stability index (CSI) was assessed as per the method of Sairam et al. [31].

\subsection{Photosynthetic Characteristics}

Photosynthetic traits such as net photosynthetic $\mathrm{CO}_{2}$ assimilation $(A)$, transpiration rate $(E)$ and stomatal conductance $(g s)$ were observed 60 days after limited water irrigation and the silicon supplementation period, using an LI-6800 portable photosynthesis system (LI-COR Biosciences, Lincoln, NE, United States). For each irrigation treatment, leaf gas exchange was conducted between 09:00-11:00 a.m. on treated and normal plants (five replicates). In each pot, the leaves (middle third of leaf +1 ) were used for photosynthetic parameters. Inside the leaf chamber, photosynthetic photon flux density (PPFD) was set at $1000 \mu \mathrm{mol} \mathrm{m}{ }^{-2} \mathrm{~s}^{-1}$, leaf temperature $\left(25^{\circ} \mathrm{C}\right)$, and $\mathrm{CO}_{2}$ concentration $\left(400 \mu \mathrm{mol} \mathrm{mol}^{-1}\right)$.

\subsection{Measurement of EnzymeActivities}

Approximately $500 \mathrm{mg}$ of fresh sugarcane leaves were frozen in liquid nitrogen and extracted in $50 \mathrm{mM}$ potassium phosphate buffer (PBS, $\mathrm{pH} 7.8)$. Following the centrifugation $(15,000 \times g$ for $10 \mathrm{~min}$ at $4{ }^{\circ} \mathrm{C}$ ), the supernatant was collected for enzyme assays.

The catalase (CAT, EC 1.11.1.6) activity was determined according to the method as stated by Azevedo et al. [32]. Peroxidase (POD, EC 1.11.1.7) activity was quantified according to Bai et al. [33] with minor changes. The reaction mixture contained $1.0 \mathrm{~mL}$ of $0.3 \% \mathrm{H}_{2} \mathrm{O}_{2}, 1.0 \mathrm{~mL}$ of $0.05 \mathrm{M}$ PBS 
(pH 7.8), $0.9 \mathrm{~mL}$ of guaiacol $(0.2 \%)$, mixed with the $0.1 \mathrm{~mL}$ of enzyme extract. The absorbance of the mixture was observed at $470 \mathrm{~nm}$.

The superoxide dismutase (SOD, EC 1.15.1.1) activity was estimated based on the inhibition of nitroblue tetrazolium (NBT) photo inhibition reduction $[17,34]$ with minor modifications. The reaction

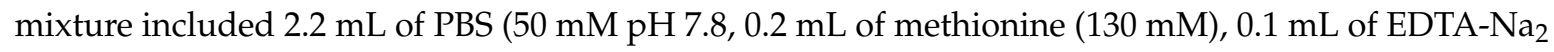
$(20 \mu \mathrm{M}), 0.2 \mathrm{~mL}$ of NBT $(750 \mu \mathrm{M}), 0.2 \mathrm{~mL}$ of riboflavin $(100 \mu \mathrm{M})$ mixed with $0.1 \mathrm{~mL}$ of the enzyme solution. The specific SOD activity was expressed as the amount of enzyme required that produced $50 \%$ inhibition of NBT reduction under assay conditions.

\subsection{Determination of Proline and Malondialdehyde Content}

Proline content was estimated by the acid-ninhydrin method according to Bates et al. [35]. The $500 \mathrm{mg}$ fresh leaf samples were homogenized in $10 \mathrm{~mL}$ aqueous sulphosalicylic acid (3\%) and centrifuged $(3500 \times g, 10 \mathrm{~min})$. The extract $(2 \mathrm{~mL})$ was treated with two $\mathrm{ml}$ acid ninhydrin and two $\mathrm{ml}$ glacial acetic acid, the reaction mixture was shifted in water bath $\left(100^{\circ} \mathrm{C}, 1 \mathrm{~h}\right)$, and immediately cooled to stop the reaction. The mixture was extracted with four $\mathrm{ml}$ of toluene. The absorbance of the pink colored layers was measured at $520 \mathrm{~nm}$, using toluene as blank. The proline content was quantified from a standard calibration curve.

The malondialdehyde (MDA) contents in sugarcane leaves were monitored based on the thiobarbituric acid according to the Bailly et al. [36], with minor changes. The $500 \mathrm{mg}$ leaf samples were homogenized in $8 \mathrm{~mL}$ of trichloroacetic acid $(0.1 \%, w / v)$; the mixture was centrifuged at $5000 \times g(10 \mathrm{~min}$, $4{ }^{\circ} \mathrm{C}$ ), and supernatant was used for further analysis. Equal volume (1:1) of supernatant was mixed with $0.5 \%(w / v)$ of thiobarbituric acid in $5 \%(w / v)$ trichloroacetic acid, boiled $(20 \mathrm{~min})$, and immediately cooled to stop the reaction. After centrifugation $(8000 \times g, 10 \mathrm{~min})$, the absorbance of the mixture was determined at 450, 532 and $600 \mathrm{~nm}$.

\subsection{Determination of Silicon Content}

Silicon content was determined according to method used by Wang et al. [37] with minor changes. The leaf samples were collected, washed and fully dried $\left(65^{\circ} \mathrm{C}\right)$ up to constant weight. Then, $200 \mathrm{mg}$ of dried leaf powder from each sample was digested with a microwave digestion system using seven $\mathrm{ml}$ of oxidizing solution $\left(\mathrm{HNO}_{3}-\right.$ six $\mathrm{ml}$ and $30 \% \mathrm{H}_{2} \mathrm{O}_{2}-$ one $\left.\mathrm{ml}\right)$ for half an hour $\left(150{ }^{\circ} \mathrm{C}-10 \mathrm{~min}\right.$ and $180^{\circ} \mathrm{C}-20 \mathrm{~min}$ ). Prior to analysis, the digested extract was diluted with deionized water up to $100 \mathrm{~mL}$ (final volume). The concentration of silicon in each digested sample was quantified by inductively coupled plasma-optical emission spectroscopy (ICP-OES optima 8300, Perkin Elmer, MA, USA), calibrated by standard solution.

\subsection{Measurement of Growth and Biomass Traits}

The plant length and leaf area-expansion were measured by a measuring tape meter and Leaf Area Meter (CI-203 Area Meter, CID, Inc., USA). After sixty-days of treatment, the sugarcane plants were harvested, washed with irrigation water, and weighted. The fresh leaves, stems and roots were placed in paper bags and oven-dried at $65^{\circ} \mathrm{C}$, and the dry biomass of the plant organs was determined until the constant weight.

\subsection{The Model}

Physiological and biochemical activities in sugarcane are dependent on the applied doses of the silicon in the soil. The present experiment shows that silicon application under limited irrigation levels (\% of soil moisture) significantly up-regulated the photosynthetic and biochemical activities of sugarcane. It is hypothesized that the frequency of change (\% increase) in physiological and antioxidant 
activities with respect to Si application in soil is directly proportional to the concentration of silicon supplied in the soil. Mathematically, it can be expressed as:

$$
\frac{d P}{d S} \propto S
$$

where $P=$ Photosynthetic parameters, i.e., photosynthetic $\mathrm{CO}_{2}$ assimilation rate, transpiration and stomatal conductance, $S=$ concentration of silicon supplied, $d P=$ incremental variations in photosynthetic characteristics due to increasing concentrations of silicon $(d S), d S=$ increasing concentrations of silicon.

\subsection{Governing Equation}

The above hypothesis can be translated into a governing equation by introducing a proportionality constant $(K)$ as below.

$$
\frac{d P}{d S}=K S
$$

where $K=$ proportionality constant and is also known as base response $(\lambda)$. The actual base responses of photosynthetic capacity in control plants.

\subsection{Solution}

Variables of Equation (2) were separated and written as below.

$$
\int d P=\lambda \int S d S
$$

Solving above governing equation following solution would be obtained.

$$
P_{S}=\frac{\lambda}{2} S^{2}+I
$$

where $P S=$ Physiological responses against applied doze of silicon; $I=$ integration constant, which can be worked out by substituting the initial conditions in Equation (4), i.e., $S=0, P_{S}=\lambda$.

$$
\begin{gathered}
\lambda=\frac{\lambda}{2} \times 0+I \\
I=\lambda
\end{gathered}
$$

Substituting value of the integration constant in Equation (4), the general solution can be written as below.

$$
P=\lambda+\frac{\lambda}{2} S^{2}
$$

or

$$
P_{S}=\lambda\left(1+\frac{1}{2} S^{2}\right)
$$

The expression within parenthesis is an approximation of cosine function, hence the solution can be written as below.

$$
P_{S}=\lambda(\cos S)
$$

The solution can be further generalized by providing flexibility to re-orient the curve against the $x$ and $y$ axis besides adjusting amplitude and wavelength. Equation (9) can be re-written as below.

$$
P_{S}=\alpha+\lambda \cos (\beta S+\omega)
$$


The constant $\alpha$ decides the shifting of the cosine curve with respect to the $x$-axis. The constant $\beta$, $\omega$ decides the frequency or wavelength and lateral shifting ( $y$-axis) of the cosine function. The coefficient $\lambda$ (base response) decides the significance of the amplitude of cosine function.

\subsection{Statistical Analysis}

All values were represented as the means. One-way analysis of variance (ANOVA) was used to analyze the significance of the differences among different irrigation levels. Two-way ANOVA was performed to analyze the interaction between $\mathrm{Si}$ and limited water irrigation.

\section{Results}

\subsection{Impact of Silicon on Growth and Biomass under Limited Water Irrigation}

Growth and biomass traits were measured in terms of plant length, number of leaf-area expansion, fresh and dry mass reduced significantly $(p<0.05)$ following limited irrigation in sugarcane plants. Irrigation with $80-75,55-50$ and $35-30 \%$ of soil moisture decreased plant length $(\sim 26-67 \%)$, number of leaves-area expansion ( 39-67, 7-51\%), fresh biomass ( 18-59\%) and dry biomass ( 18-66\%) in sugarcane plants, respectively, as compared to the normal irrigation like $100-95 \%$ of soil moisture. On the other hand, Si supplied along with limited water irrigation alleviated the reduction in plant growth and biomass, as percentage increased (Tables 1 and 2). However, the concentration of Si enhanced growth and biomass of sugarcane plants was over the values of normal irrigation. Thus, the data indicated that $400 \mathrm{mg} \mathrm{Si} \mathrm{L}^{-1}$ was more effective compared to $100-300$ and $500 \mathrm{mg} \mathrm{Si} \mathrm{L}^{-1}$ in reducing the $80-75,55-50$ and $35-30 \%$ of soil moisture.

Table 1. Effect of silicon (0, 100, 200, 300, 400 and $\left.500 \mathrm{mg} \mathrm{Si} \mathrm{L}^{-1}\right)$ on plant length (PL), Leaf number (LN), leaf area-expansion (LAE), and leaf water content (LWC) in sugarcane plants exposed to 100-95, $80-75,55-50$ and $35-30 \%$ of soil moisture (SM). Data are means \pm SE $(n=5)$.

\begin{tabular}{|c|c|c|c|c|c|}
\hline Silicon $\left[\mathrm{mg} \mathrm{L}^{-1}\right]$ & SML [\%] & PL $[\mathrm{cm}]$ & LN & LAE $\left[\mathrm{m}^{2}\right.$ plant $\left.^{-1}\right]$ & LWC [\%] \\
\hline 0 & 100-95 & $112 \pm 10 \mathrm{af}$ & $18 \pm 3 a c$ & $0.7504 \pm 0.006 a j$ & $92.85 \pm 2.8 \mathrm{ah}$ \\
\hline 100 & & $117 \pm 13 \mathrm{e}$ & $16 \pm 2 \mathrm{ej}$ & $0.7622 \pm 0.003 h$ & $93.03 \pm 1.9 \mathrm{~g}$ \\
\hline 200 & & $114 \pm 8 d$ & $19 \pm 2 \mathrm{aeg}$ & $0.7501 \pm 0.007 \mathrm{al}$ & $93.08 \pm 3.6 \mathrm{aef}$ \\
\hline 300 & & $122 \pm 5 i j$ & $18 \pm 3 b e$ & $0.7553 \pm 0.008 \mathrm{ad}$ & $93.01 \pm 2.5$ ade \\
\hline 400 & & $120 \pm 9 h i$ & $18 \pm 2 \mathrm{ad}$ & $0.7789 \pm 0.010 \mathrm{cl}$ & $92.98 \pm 2.0 \mathrm{ah}$ \\
\hline 500 & & $118 \pm 11 \mathrm{akj}$ & $16 \pm 3 a i$ & $0.7698 \pm 0.008 n$ & $93.03 \pm 3.1$ adi \\
\hline 0 & $80-75$ & $83 \pm 5 a d p$ & $11 \pm 1 d$ & $0.7019 \pm 0.011 \mathrm{ap}$ & $76.03 \pm 2.7 \mathrm{fn}$ \\
\hline 100 & & $85 \pm 7 \mathrm{al}$ & $11 \pm 2 \mathrm{eh}$ & $0.7141 \pm 0.004 \mathrm{o}$ & $76.45 \pm 1.7 \mathrm{ac}$ \\
\hline 200 & & $89 \pm 11 \mathrm{hi}$ & $13 \pm 2 \mathrm{fi}$ & $0.7188 \pm 0.014 \mathrm{ak}$ & $77.61 \pm 2.0 \mathrm{hi}$ \\
\hline 300 & & $95 \pm 10$ aok & $14 \pm 3$ ghi & $0.7250 \pm 0.009 a p$ & $79.33 \pm 2.3 \mathrm{adg}$ \\
\hline 400 & & $101 \pm 6 a m$ & $14 \pm 2 d$ & $0.7318 \pm 0.006$ egi & $79.87 \pm 2.7 \mathrm{ac}$ \\
\hline 500 & & $100 \pm 8$ aeh & $13 \pm 2 f$ & $0.7276 \pm 0.011 \mathrm{gh}$ & $78.92 \pm 1.8 \mathrm{e}$ \\
\hline 0 & $55-50$ & $48 \pm 3 e f$ & $8 \pm 1$ ae & $0.5009 \pm 0.016 \mathrm{~d}$ & $63.01 \pm 1.1 \mathrm{ai}$ \\
\hline 100 & & $48 \pm 5 \mathrm{ad}$ & $8 \pm 3 i$ & $0.5091 \pm 0.019 \mathrm{ef}$ & $64.11 \pm 1.3 n$ \\
\hline 200 & & $50 \pm 5 a n$ & $9 \pm 2 a j$ & $0.5108 \pm 0.009$ ae & $64.06 \pm 0.9 f$ \\
\hline 300 & & $52 \pm 7 f$ & $9 \pm 1 \mathrm{af}$ & $0.5209 \pm 0.011 \mathrm{mn}$ & $66.29 \pm 1.0 \mathrm{de}$ \\
\hline 400 & & $53 \pm 4 a b$ & $11 \pm 2 n$ & $0.5301 \pm 0.013 a n$ & $69.87 \pm 1.3 p c$ \\
\hline 500 & & $53 \pm 3 a$ & $10 \pm$ 2ade & $0.5248 \pm 0.009 \mathrm{ci}$ & $69.02 \pm 0.8 \mathrm{~m}$ \\
\hline 0 & $35-30$ & $37 \pm 2 c e$ & $6 \pm 1 \mathrm{aj}$ & $0.3678 \pm 0.007 \mathrm{fg}$ & $40.11 \pm 0.5 \mathrm{gh}$ \\
\hline 100 & & $37 \pm 41$ & $6 \pm 2 c j$ & $0.3706 \pm 0.005 \mathrm{hi}$ & $40.83 \pm 0.8 \mathrm{op}$ \\
\hline 200 & & $37 \pm 4 \mathrm{ki}$ & $6 \pm 1 n$ & $0.3817 \pm 0.007 \mathrm{ae}$ & $41.51 \pm 1.1 \mathrm{ahi}$ \\
\hline 300 & & $40 \pm 3 a j$ & $7 \pm 21$ & $0.3873 \pm 0.009$ afi & $41.96 \pm 0.71$ \\
\hline 400 & & $42 \pm 2 h$ & $8 \pm 2$ ap & $0.4006 \pm 0.005 a j$ & $43.07 \pm 1.3 \mathrm{aj}$ \\
\hline 500 & & $42 \pm 3$ eg & $8 \pm$ 1ace & $0.3903 \pm 0.013$ ade & $42.63 \pm 1.2$ ace \\
\hline \multicolumn{6}{|c|}{ Variation factor } \\
\hline $\mathrm{Si}$ & & $* *$ & NS & $* *$ & $* *$ \\
\hline \multicolumn{2}{|c|}{ SML } & NS & $* *$ & NS & NS \\
\hline \multicolumn{2}{|c|}{$\mathrm{Si} \times \mathrm{SML}$} & $* *$ & $* *$ & $* *$ & $* *$ \\
\hline
\end{tabular}

Different values within a column followed by different letters indicate significant $(p<0.05$, Student t-test) differences. NS and ${ }^{* *}$ represent non-significant and significant, respectively. 
Table 2. Quality of the sugarcane harvested at 60 days after Si application against limited water irrigation such as 100-95, 80-75, 55-50 and 35-30\% of soil moisture. Lfm—leaf fresh, Ldm—leaf dry mass, Sfm—stem fresh, Sdm—stem dry mass, Rfm root fresh, Rdm—root dry mass, Tfm—total fresh, and Tdm—total dry mass. Data are means \pm SE of three replicates in each irrigation levels.

\begin{tabular}{|c|c|c|c|c|c|c|c|c|c|}
\hline \multirow{2}{*}{ Silicon [mg L ${ }^{-1}$ ] } & \multirow{2}{*}{ SML [\%] } & \multicolumn{8}{|c|}{ Biomass [g] } \\
\hline & & Lfm & Ldm & Sfm & Sdm & Rfm & Rdm & Tfm & Tdm \\
\hline 0 & $100-95$ & $212.55 \pm 10.1 \mathrm{ac}$ & $69.96 \pm 3.31 a$ & $969.71 \pm 9.3 \mathrm{ad}$ & $229.78 \pm 13.1 \mathrm{ai}$ & $129.79 \pm 4.1 b c$ & $51.11 \pm 1.8 \mathrm{bce}$ & $1312.05 \pm 22.5 \mathrm{gh}$ & $350.85 \pm 5.8 \mathrm{ae}$ \\
\hline 100 & & $210.85 \pm 7.3 \mathrm{pi}$ & $68.11 \pm 2.3 j$ & $979.45 \pm 7.1 p$ & $230.19 \pm 9.8 \mathrm{~cd}$ & $132.59 \pm 3.7 \mathrm{ef}$ & $51.33 \pm 1.1 \mathrm{ci}$ & $1322.89 \pm$ 19.1aei & $349.63 \pm 6.3 \mathrm{bgi}$ \\
\hline 200 & & $215.25 \pm 13.3 \mathrm{od}$ & $70.18 \pm 2.1 \mathrm{kl}$ & $974.04 \pm 7.7 \mathrm{ci}$ & $230.08 \pm 7.6 \mathrm{bde}$ & $134.11 \pm 3.3 \mathrm{~cd}$ & $52.08 \pm 1.4 \mathrm{de}$ & $1323.4 \pm 17.8 \mathrm{hi}$ & $352.34 \pm 9.1 \mathrm{ac}$ \\
\hline 300 & & $213.71 \pm 6.9 \mathrm{mn}$ & $68.98 \pm 1.8 \mathrm{ac}$ & $978.87 \pm 6.8 \mathrm{op}$ & $231.19 \pm 10.1 \mathrm{ae}$ & $137.03 \pm 3.9 a$ & $53.21 \pm 0.9 \mathrm{e}$ & $1329.61 \pm 23.3 \mathrm{ef}$ & $353.38 \pm 5.8$ de \\
\hline 400 & & $218.13 \pm 10.1 \mathrm{ca}$ & $71.05 \pm 1.3 \mathrm{ac}$ & $979.89 \pm 5.3 \mathrm{ai}$ & $231.33 \pm 12.5 f$ & $138.89 \pm 2.8 \mathrm{ac}$ & $53.95 \pm 1.1 \mathrm{ad}$ & $1336.91 \pm 17.5 \mathrm{dei}$ & $356.33 \pm 7.4 \mathrm{e}$ \\
\hline 500 & & $216.01 \pm 7.9 \mathrm{df}$ & $69.59 \pm 1.9 b$ & $986.66 \pm 8.1 \mathrm{~m}$ & $232.06 \pm 11.3 \mathrm{ad}$ & $141.07 \pm 3.5 \mathrm{ec}$ & $95.24 \pm 1.7 \mathrm{~g}$ & $1343.74 \pm 21.2 \mathrm{e}$ & $396.89 \pm 10.1 b c$ \\
\hline 0 & $80-75$ & $191.91 \pm 3.9 \mathrm{ad}$ & $61.85 \pm 1.2 \mathrm{fi}$ & $765.95 \pm 5.8 \mathrm{no}$ & $183.08 \pm 7.6 \mathrm{i}$ & $122.37 \pm 4.1$ aei & $43.08 \pm 0.7 \mathrm{af}$ & $1080.23 \pm 13.1 \mathrm{aef}$ & $288.01 \pm 8.4 \mathrm{ai}$ \\
\hline 100 & & $192.05 \pm 4.2 \mathrm{bl}$ & $62.03 \pm 1.3 \mathrm{ce}$ & $766.03 \pm 6.3 \mathrm{ad}$ & $183.23 \pm 7.1 b c$ & $123.98 \pm 2.2 \mathrm{~g}$ & $43.70 \pm 0.9 \mathrm{ig}$ & $1082.06 \pm 9.8 b c$ & $288.96 \pm 7.9 \mathrm{ef}$ \\
\hline 200 & & $195.81 \pm 4.1 \mathrm{ai}$ & $63.81 \pm 1.7 \mathrm{~g}$ & $769.07 \pm 4.81$ & $183.87 \pm 8.5 \mathrm{~g}$ & $124.08 \pm 2.9 j$ & $44.01 \pm 1.3 \mathrm{kn}$ & $1088.96 \pm 17.2 \mathrm{ae}$ & $291.69 \pm 4.7 \mathrm{ak}$ \\
\hline 300 & & $196.64 \pm 5.6$ ace & $84.54 \pm 2.3 \mathrm{~h}$ & $774.25 \pm 5.1 \mathrm{ai}$ & $184.11 \pm 6.2 \mathrm{ab}$ & $125.81 \pm 3.11$ & $45.49 \pm 1.1 \mathrm{ah}$ & $1096.7 \pm 10.2 \mathrm{k}$ & $314.14 \pm 5.8 \mathrm{ajk}$ \\
\hline 400 & & $201.03 \pm 4.1 \mathrm{cn}$ & $85.76 \pm 1.6 \mathrm{bc}$ & $778.01 \pm 4.9 \mathrm{k}$ & $185.23 \pm 5.3 \mathrm{~h}$ & $128.13 \pm 2.2 \mathrm{ah}$ & $46.33 \pm 1.2 \mathrm{al}$ & $1107.17 \pm 17.8 \mathrm{~lm}$ & $317.32 \pm 6.1$ agh \\
\hline 500 & & $198.63 \pm 3.9 \mathrm{op}$ & $85.03 \pm 2.1 \mathrm{~d}$ & $775.81 \pm 6.3 b$ & $184.82 \pm 7.1 \mathrm{k}$ & $127.44 \pm 1.8 \mathrm{acn}$ & $46.08 \pm 1.7 \mathrm{an}$ & $1101.88 \pm 13.3$ ao & $315.93 \pm 4.1 \mathrm{al}$ \\
\hline 0 & $55-50$ & $112.55 \pm 3.2 \mathrm{ai}$ & $39.96 \pm 2.3 \mathrm{ef}$ & $543.30 \pm 4.1 \mathrm{c}$ & $113.80 \pm 4.31 \mathrm{~lm}$ & $98.21 \pm 1.1 \mathrm{~m}$ & $30.70 \pm 0.9 \mathrm{jk}$ & $754.06 \pm 11.8 \mathrm{an}$ & $184.46 \pm 4.3 \mathrm{aeh}$ \\
\hline 100 & & $112.85 \pm 2.9 \mathrm{ai}$ & $40.01 \pm 1.1 \mathrm{ac}$ & $544.08 \pm 3.9 \mathrm{ef}$ & $113.95 \pm 3.6 \mathrm{j}$ & $98.46 \pm 1.9 \mathrm{ajk}$ & $31.11 \pm 0.3 \mathrm{o}$ & $755.39 \pm 13.3 \mathrm{j} 1$ & $185.07 \pm 5.1 \mathrm{ai}$ \\
\hline 200 & & $115.31 \pm 2.6 \mathrm{gh}$ & $40.64 \pm 1.7 \mathrm{fh}$ & $545.89 \pm 5.5 \mathrm{~d}$ & $114.25 \pm 2.8 \mathrm{ao}$ & $99.03 \pm 1.6 a e$ & $31.68 \pm 0.9 \mathrm{am}$ & $760.23 \pm 9.1 \mathrm{ai}$ & $186.57 \pm 6.1$ aop \\
\hline 300 & & $118.76 \pm 3.3 \mathrm{ah}$ & $41.18 \pm 1.3 \mathrm{ae}$ & $546.81 \pm 2.8 \mathrm{fh}$ & $114.53 \pm 4.1 \mathrm{acn}$ & $101.13 \pm 1.5 \mathrm{ao}$ & $33.03 \pm 0.5 \mathrm{ai}$ & $766.7 \pm 13.5$ hik & $188.74 \pm 3.8 n$ \\
\hline 400 & & $123.96 \pm 2.1 \mathrm{k}$ & $41.91 \pm 1.4 \mathrm{a}$ & $551.11 \pm 3.7 \mathrm{~h}$ & $115.08 \pm 3.9 p$ & $104.28 \pm 2.1 \mathrm{ci}$ & $34.23 \pm 0.5 \mathrm{aeg}$ & $779.35 \pm 17.4 \mathrm{am}$ & $191.22 \pm 5.2$ ace \\
\hline 500 & & $120.72 \pm 2.7 \mathrm{j}$ & $40.88 \pm 1.2 \mathrm{~m}$ & $548.25 \pm 3.2$ aj & $114.68 \pm 5.7$ ace & $102.34 \pm 1.3 \mathrm{ab}$ & $34.08 \pm 0.4 p$ & $771.31 \pm 9.6 \mathrm{ae}$ & $189.64 \pm 4.1 \mathrm{am}$ \\
\hline 0 & $35-30$ & $55.85 \pm 1.8 \mathrm{ai}$ & $18.16 \pm 0.8 \mathrm{ap}$ & $413.15 \pm 5.8 \mathrm{~g}$ & $83.67 \pm 2.1 \mathrm{ai}$ & $68.05 \pm 1.1 \mathrm{ai}$ & $15.95 \pm 0.3 \mathrm{ai}$ & $537.05 \pm 5.8 \mathrm{eg}$ & $117.78 \pm 3.7 \mathrm{ai}$ \\
\hline 100 & & $56.36 \pm 2.3 \mathrm{bc}$ & $18.21 \pm 0.31 \mathrm{~m}$ & $413.65 \pm 4.2 \mathrm{abe}$ & $84.03 \pm 4.7 \mathrm{bc}$ & $68.63 \pm 1.3 \mathrm{ap}$ & $16.16 \pm 0.2 \mathrm{ab}$ & $538.64 \pm 9.2 p$ & $118.4 \pm 3.7 \mathrm{fgh}$ \\
\hline 200 & & $57.82 \pm 1.9 \mathrm{ac}$ & $18.91 \pm 0.5 \mathrm{ai}$ & $415.58 \pm 3.3 \mathrm{i}$ & $83.11 \pm 2.7 \mathrm{af}$ & $69.11 \pm 1.4 \mathrm{ac}$ & $16.93 \pm 0.2 \mathrm{ce}$ & $542.51 \pm 9.3 \mathrm{ce}$ & $118.95 \pm 3.1 \mathrm{ap}$ \\
\hline 300 & & $58.70 \pm 1.1 \mathrm{de}$ & $19.02 \pm 0.4 \mathrm{~m}$ & 416.ac41 \pm 3.9 & $83.29 \pm 1.9 \mathrm{ac}$ & $69.80 \pm 0.9 \mathrm{~cd}$ & $17.21 \pm 0.3 \mathrm{a}$ & $544.91 \pm 9.1 \mathrm{ab}$ & $119.52 \pm 1.9 \mathrm{ac}$ \\
\hline 400 & & $61.08 \pm 1.1 \mathrm{af}$ & $19.93 \pm 0.4 \mathrm{ad}$ & 419.73ai \pm 3.9 & $84.02 \pm 1.1 \mathrm{ai}$ & $71.23 \pm 0.9 \mathrm{ci}$ & $18.16 \pm 0.3 \mathrm{aoo}$ & $552.04 \pm 7.2 \mathrm{ef}$ & $122.11 \pm 2.3 \mathrm{ae}$ \\
\hline 500 & & $61.01 \pm 1.9 \mathrm{ae}$ & $19.34 \pm 0.2 \mathrm{aeg}$ & $417.50 \pm 4.3$ ade & $83.91 \pm 0.9 \mathrm{adg}$ & $71.08 \pm 1.2 \mathrm{aef}$ & $18.11 \pm 0.2 \mathrm{de}$ & $549.59 \pm 5.6 \mathrm{de}$ & $121.36 \pm 1.7$ ace \\
\hline
\end{tabular}

Different letters represent statistically significant differences $(p<0.05)$. 
The application of $\mathrm{Si}$ as soil irrigation facilitated plant performance and was significantly up-regulated compared to that in limited water supply. The plant development showed a substantial improvement with the increasing level of Si application. As shown in Table 2, the fresh and dry mass of leaves, stems and roots of sugarcane plants were markedly declined against limited water irrigation as compared to normal irrigation, while the negative effects of limited water supply on biomass were positively mitigated and gradually enhanced with increasing levels of $\mathrm{Si}$ applied as soil irrigation. Biomass was initially up-regulated with the Si levels (100-400 $\mathrm{mg} \mathrm{Si} \mathrm{L}^{-1}$ ) and then declined considerably at a higher concentration of $\mathrm{Si}\left(500 \mathrm{mg} \mathrm{Si} \mathrm{L}^{-1}\right)$.

\subsection{Impact of Leaf Gas Exchange Characteristics}

Photosynthetic traits declined during the whole plant growth stage during limited water irrigation like 100-95, 80-75, 55-50 and 35-30\% of soil moisture (Figure 2A). At all irrigation treatments, $A, g s$ and $E$ under $\mathrm{Si}$ application were found higher without $\mathrm{Si}$, at 60 days after $\mathrm{Si}$ applied. Photosynthesis for all Si-treated plants were found higher as $2-5,10-25,1-48$ and $0.5-60 \%$ than that without Si application, i.e., $100-95,80-75,55-50$ and $35-30 \%$ of soil moisture (Figure 2A). As shown in Figure 2B,C, limited water irrigation caused a severe loss in $g s(\sim 61 \%)$ and $E(\sim 63 \%)$ in $35-30 \%$ of soil moisture in sugarcane plants. However, soil irrigation with various concentrations of $\mathrm{Si}$ obviously mitigated the water stress-induced decrease in $g \mathrm{~s}$ and $E$. The $100-95,80-75,55-50$ and $35-30 \%$ of soil moisture irrigations with Si fertilizer up-regulated $g$ s by $1-44,3-49,3-50$ and $11-74 \%$ and $E$ by $1-29,0.1-27,0.7-66$ and 9-67\%, over the free from $\mathrm{Si}$ application, respectively. Fertilization of $\mathrm{Si}$ with irrigated water also noted remarkable differences in $A, g$ s and $E$ parameters. However, $A, g s$ and $E$ were markedly up-regulated at $100-400 \mathrm{mg} \mathrm{Si} \mathrm{L}^{-1}$, and later significantly inhibited at the $500 \mathrm{mg} \mathrm{L}^{-1} \mathrm{Si}$ concentration. The $A$, gs and $E$ values were found the highest at $400 \mathrm{mg} \mathrm{Si} \mathrm{L}^{-1}$ as compared to $100-300$ and $500 \mathrm{mg} \mathrm{Si} \mathrm{L}^{-1}$ with limited soil moisture. These data showed that $\mathrm{Si}$ applied with irrigation could mitigate the negative effects of drought on sugarcane plants.

\subsection{Photosynthetic Pigments, Leaf Greenness (SPAD Value) and Relative Water Content}

At sixty days after soil irrigation with $\mathrm{Si}$, chlorophylls and SPAD values were significantly higher in the Si-supplied plants than in those without $\mathrm{Si}$ (Figure 2D,G). Our results showed that limited water irrigation decreased the chlorophyll and SPAD values compared to those of normal irrigation (100-95\% of soil moisture). The irrigation treatment with $400 \mathrm{mg} \mathrm{Si} \mathrm{L}^{-1}$ was more effective, which increased Chl $a, b, a+b$ and SPAD values by $6,8,9$ and $10 \%$, respectively, as compared to the treatment with 100-300 and $500 \mathrm{mg} \mathrm{L}^{-1}$ of silicon. Likewise, the highest content of chlorophyll and SPAD values were also calculated for $100 \mathrm{mg}$ of Si supply.

Chlorophyll stability index (CSI) was observed in sugarcane plants with silicon against limited water irrigation (Figure 2H). The CSI percentage in sugarcane plants were markedly decreased up to $35-30 \%$ of soil moisture as compared to well irrigated plants. CSI was gradually increased with increasing levels of $\mathrm{Si}$ with limited water supply. The highest percentage was found to be $\sim 11,13$ and $16 \%$ in $500 \mathrm{mg} \mathrm{Si} \mathrm{L}^{-1}$ as compared to $100 \mathrm{mg} \mathrm{Si} \mathrm{L}^{-1}$, respectively.

Leaf relative water content (RWC) is the main sign that shows water status and survival percentage of the plants against unfavourable environmental conditions. A significant loss in the RWC of stressed sugarcane plants was found as compared to normal irrigation (Table 1). On the other hand, there was a significant maintenance or improvement in RWC in the treatment with Si against limited water irrigation. The most substantial increase of up to $11 \%$ was found in $400 \mathrm{mg} \mathrm{L}^{-1}$ applied Si, as compared to normal irrigation free from silicon. 

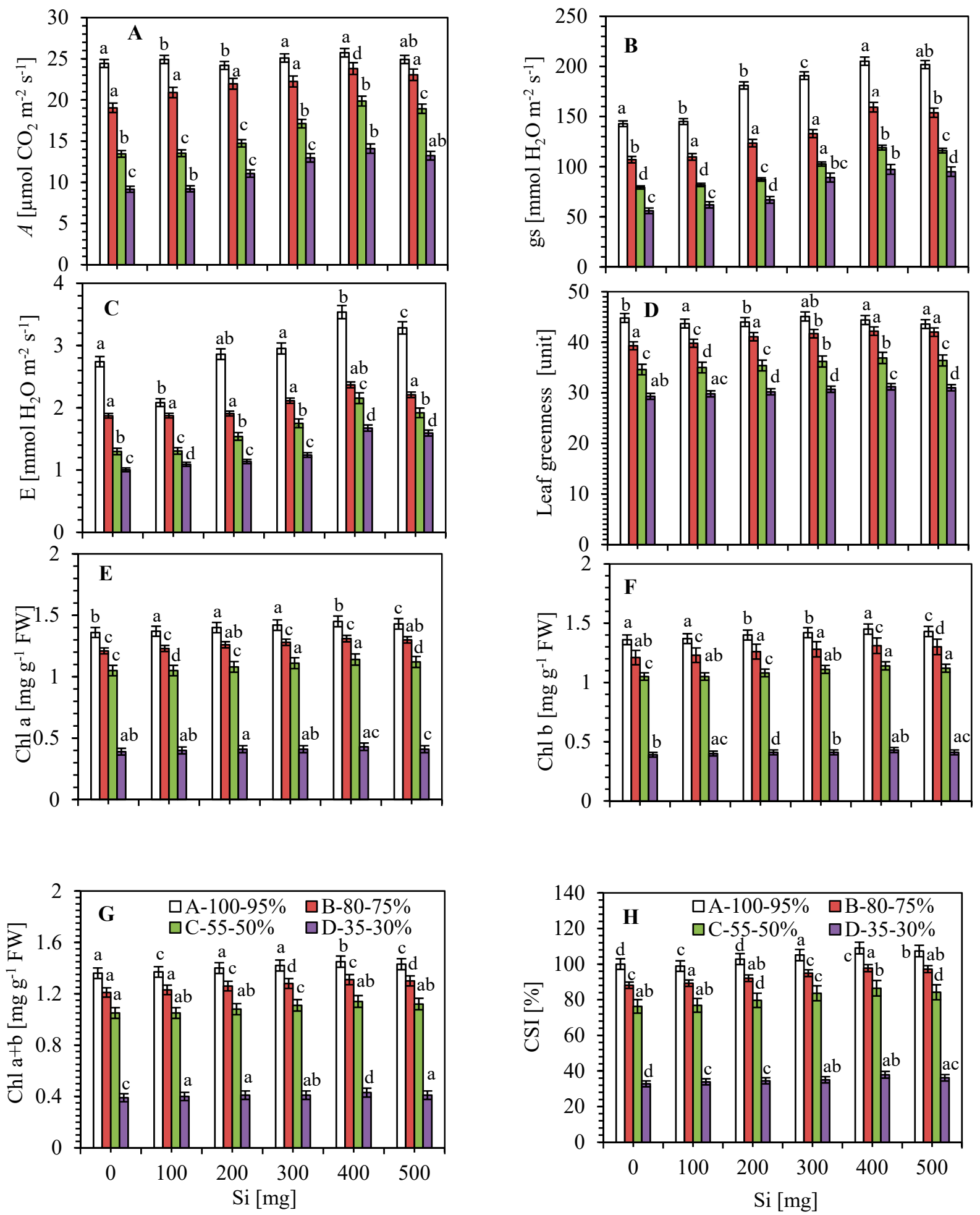

Figure 2. Changes of (A) net photosynthetic $\mathrm{CO}_{2}$ assimilation rate $\left(A ; \mu \mathrm{mol} \mathrm{CO}_{2} \mathrm{~m}^{-1} \mathrm{~s}^{-1}\right),(\mathbf{B})$ stomatal conductance $\left(g s ; \mathrm{mmol} \mathrm{H}_{2} \mathrm{O} \mathrm{m}^{-2} \mathrm{~s}^{-1}\right)$, (C) transpiration rate $\left(E ; \mathrm{mmol} \mathrm{H}_{2} \mathrm{O} \mathrm{m}^{-2} \mathrm{~s}^{-1}\right)$, (D) leaf greenness-SPAD value (units), (E-G) photosynthetic pigments (Chl; $\mathrm{mg} \mathrm{g}^{-1} \mathrm{FW}$ ) and $(\mathbf{H})$ chlorophyll stability index (CSI; \%) after silicon application $\left(0,100,200,300,400\right.$ and $\left.500 \mathrm{mg} \mathrm{L}^{-1}\right)$ against normal $(100-95 \%)$ and limited water irrigations such as $80-75,55-50$ and $35-30 \%$ of soil moisture in sugarcane plants. Bar indicates $\pm \mathrm{SD}(n=5)$. Different letters represent significant differences at $p<0.05$ level. 


\subsection{Impact of Si on the Activities of Antioxidants against Limited Water Irrigation}

In order to assess the role of $\mathrm{Si}$ in the regulation of antioxidant enzyme activities and the relationship between reactive oxygen species (ROS) and the cellular defense system, the activities of CAT, POD and SOD were examined. The data in Figure 3A,C,E show that limited water irrigation significantly $(p<0.05)$ decreased CAT (ca. 10-52\%), POD $(\sim 4-35 \%)$ and SOD $(\sim 10-44 \%)$ activities in sugarcane at 60 days after limited water irrigation.
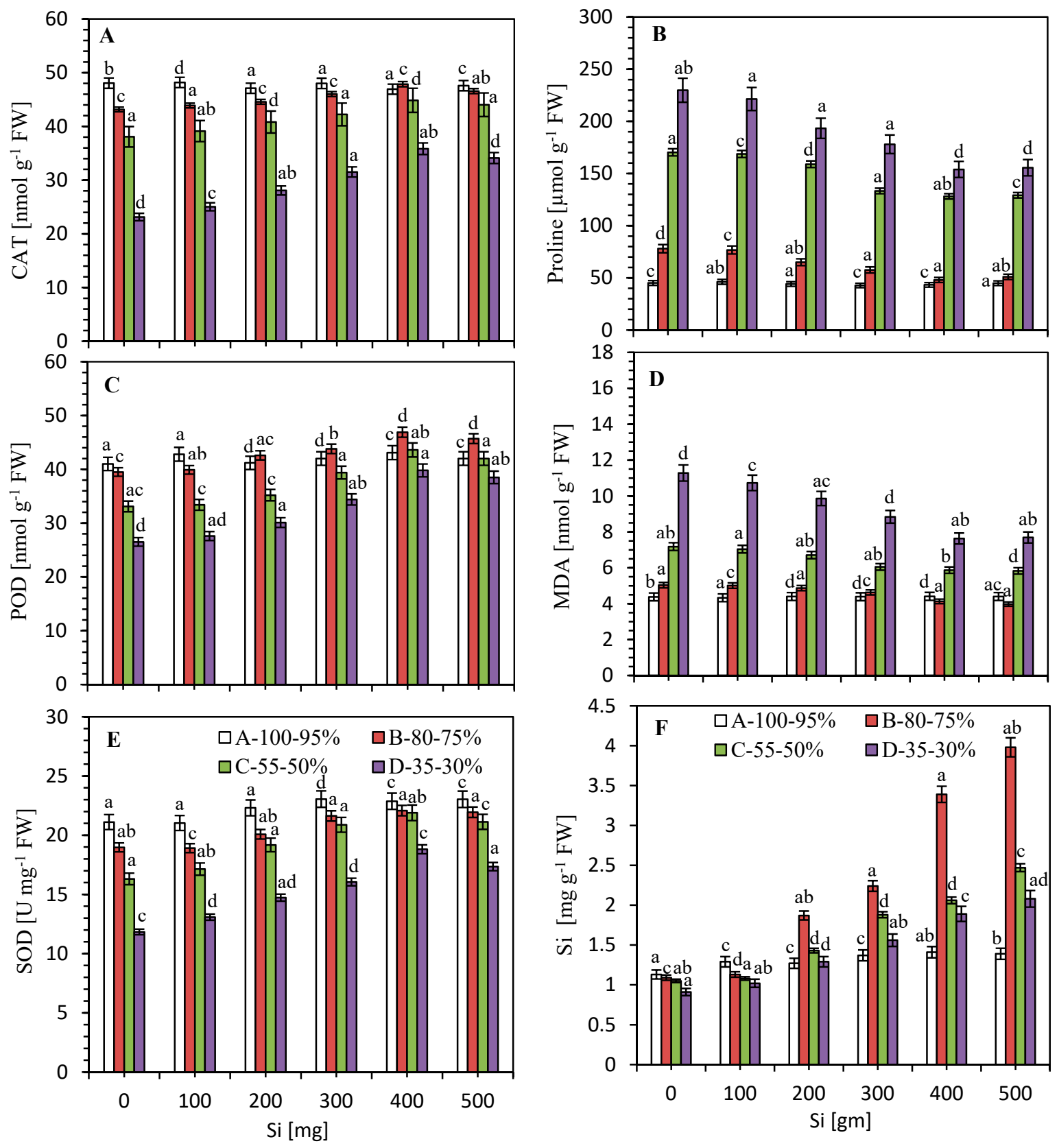

Figure 3. Effect of antioxidant enzymatic activities such as (A) catalase (CAT; $\left.\mathrm{nmol} \mathrm{g}^{-1} \mathrm{FW}\right),(\mathbf{C})$ peroxidase (POD; $\left.\mathrm{nmol} \mathrm{g}^{-1} \mathrm{FW}\right),(\mathrm{E})$ superoxide dismutase (SOD; unit $\mathrm{mg}^{-1} \mathrm{FW}$ ) and non-enzymatic activities, i.e., (B) proline content ( $\left.\mu \mathrm{mol} \mathrm{g}^{-1} \mathrm{FW}\right)$, (D) malondialdehyde content (MDA; $\left.\mathrm{nmol} \mathrm{g}^{-1} \mathrm{FW}\right)$, and (F) silicon content (Si; $\mathrm{mg} \mathrm{g}^{-1} \mathrm{FW}$ ) in sugarcane leaves on day 60 after normal and limited irrigation with silicon application $\left(0,100,200,300,400\right.$ and $\left.500 \mathrm{mg} \mathrm{L}^{-1}\right)$. Vertical bars represent \pm standard errors $(n=5)$. 
The enzymatic antioxidant activities were markedly up-regulated by the supplementation of $\mathrm{Si}$ in the plants subjected to limited water irrigation. However, the different $\mathrm{Si}$ concentrations $\left(100-500 \mathrm{mg} \mathrm{Si} \mathrm{L}{ }^{-1}\right)$ showed an increasing pattern for improving CAT, POD and SOD enzymes. The antioxidant activities were initially enhanced with increasing levels of $\mathrm{Si}$, and reached the highest percentage values of CAT- $11,18,55 \%$; POD- $19,32,50 \%$ and SOD- $16,34,59 \%$ of $80-75,55-50$ and $35-30 \%$ as compared to $100-95 \%$ of soil moisture with $400 \mathrm{mg} \mathrm{Si} \mathrm{L}^{-1}$ and limited water irrigation. The higher concentration of $\mathrm{Si}\left(500 \mathrm{mg} \mathrm{L}^{-1}\right.$ ) slightly decreased the enzymatic activities as compared to that of $400 \mathrm{mg} \mathrm{Si} \mathrm{L}^{-1}$, but the antioxidant activities in these irrigations were still higher as compared to the value of normal plants (Figure 3A,C,E).

\subsection{Impact of Si on Proline and MDA Content}

The Figure 3B also indicated a significant increase in proline content in sugarcane leaves during stress. Under stressed condition, the enhancement in proline content was ca. 73,278 and $410 \%$ as compared to control plants. A significant decrease in proline content (ca. 38, 25 and 33\% as compared to normal plants) was noticed in drought with Si applied plants, respectively. Although the role of proline has been postulated in various crops during abiotic stresses (i.e., water stress), a down-regulation in proline after application of Si during water stress arguably indicates recovery of relative water content, and loss in proline through degradation or reduced synthesis.

Lipid peroxidation (MDA content) is a marker to observe the impact of limited water supply on lipids. Accordingly, 80-75, 55-50 and 35-30\% of soil moisture also increased the MDA content ca. 15, 64 and 156\%, respectively, as compared to the value of normal plants (Figure 3D). Supplementation of $\mathrm{Si}$ with the limited water irrigation resulted in declined accumulation in the MDA content. On the other hand, the supplementation of Si did not influence the production of MDA in sugarcane plants. The MDA content declined by up to 20,18 and 32\% for increasing levels of Si with 80-75, 55-50 and $35-30 \%$ of soil moisture as compared to normal plants, respectively (Figure 3D).

\subsection{Impact of Silicon on Si Accumulation under Limited Water Irrigation}

The data in Figure 3F showed that, under limited water irrigations of 80-75, 55-50 and 35-30\% of soil moisture, the Si accumulation increased up to 265,135 and $129 \%$ higher, respectively, as compared to the control. The accumulated leaf Si concentration was the highest in $500 \mathrm{mg} \mathrm{L}^{-1}$ Si with limited water supply in sugarcane plants. The highest uptake (up to $265 \%$ ) was noted in $80-75 \%$ of soil moisture with $500 \mathrm{mg} \mathrm{L}^{-1} \mathrm{Si}$ concentration (Figure 3F).

\subsection{Regression Analysis}

Regression analysis was analyzed to fit the measured photosynthetic and antioxidant parameters in sugarcane plants with respect to their silicon concentration supplied in the soil to verify the hypothesis and work out the model parameters. Model characteristics $(\alpha, \beta, \lambda$ and $\omega)$ and coefficient of determination ( $r$ ) and standard error (S) were worked out from the measured values after regression analysis (Supplementary Table S2). The variations of overall growth, photosynthetic and antioxidant parameters explained by the proposed model ranging ' $r$ ' from 0.178 to 0.999 and ' $S$ ' from 0.001 to 48.015 , verifying the proposed hypothesis and developed model for explaining the changes of the observed parameters against silicon with limited water irrigation levels.

\section{Discussion}

All plants required sufficient amount of essential mineral nutrients to complete life cycle. The growth and biomass of plants display marked changes in response to limited water irrigation $[2,38]$. Water and mineral elements are absorbed by the plant roots, and limited water supply can have a negative impact on plant fitness through reducing root development [39]. The up-regulation of plant growth and biomass caused by silicon addition has also been noted against limited water supply $[2,40,41]$. The impact of $\mathrm{Si}$ on root growth may be due to enhanced root elongation caused by 
an increase in cell wall enlargement in the growth area [42]. The augmented water uptake during the supplementation of $\mathrm{Si}$ in limited water supply treatment is the result of maintained or improved root hydraulic conductance [43], and root growth [44].

Limited water supply also limits nutrient accumulation through root and subsequent transport to leaves via shoot, thereby minimizing nutrient supply and metabolism [45]. Silicon may play significant role in balancing the uptake, transport and distribution of mineral elements against the limited water supply [46,47]. However, the application of silicon for soil irrigation minimized the severity of limited water supply-induced growth inhibition (Tables 1 and 2). It increased sugarcane tolerance to limited water irrigation in terms of promoting the plant development. The enhancement in biomass and growth traits are attributed to the up-graded carbon assimilation due to the increased photosynthesis of Si-supplied plants [2].

Results confirmed the previous reports that an amendment of Si alleviates the water stress caused by limited water supply irrigation, and significantly affects plant growth, development and productivity, such as for Triticum spp. [48,49], Oryza sativa [44], Glycine max [50], Helianthus annuus [51] and Zea mays [52]. Silicon supplementation resulted in maximum growth and biomass, which could likely enhance soil water consumption due to enhanced leaf area-expansion and thus transpiration rate (Tables 1 and 2), which improved the stress condition [53-55]. The Si-mediated improvement in plant development not only takes place under the control condition [56], but also under the limited water supply [57].

The reduction in green pigments may mark the sign of leaf senescence. The reduction in chlorophyll content may be due to the formation of proteolytic enzymes-i.e., chlorophyllase, which is responsible for chlorophyll reduction [58] as well as damage to the photosynthetic machinery [2]. In this article, exogenous amendments with different concentrations of Si were found to significantly increase the leaf greenness (SPAD units) and photosynthetic pigments of sugarcane plants (Figure 2D-H). The supplemented silicon enhanced the photosynthetic capacity of the limited water supply and also linked to the improved efficiency of photosynthetic pigments and photosynthetic enzymes such as ribulose-bisphosphate carboxylase and $\mathrm{NADP}^{+}$dependent glyceroldehyde-3-phosphate dehydrogenase against limited soil moisture content [59]. Chloroplasts are good biosensors of stress because they are the key site for photosynthetic assimilation, a process which is more susceptible to damages caused by abiotic stresses. According to Ruiz-Espinoza et al. [60], the SPAD index depends on various factors, such as the species/variety, the diversity, the thickness, and the age of leaves.

Maintenance of the photosynthetic $\mathrm{CO}_{2}$ assimilation rate is crucial to plant growth, development and yield production. Stomatal closure was an early response to limited water supply and an effective way to decrease water loss (Figure $2 \mathrm{~B}$ ). However, it also limits $\mathrm{CO}_{2}$ diffusion into the plants, which causes the severe reduction in photosynthesis in sugarcane plants [2,61]. Addition of Si enhanced the silicon content in the leaves and thus could enhance their photosynthetic rate, but only when the plants were subjected to limited water supply (Figure 2A). The significant effects of Si at the end of drying cycle, which may be attributed to more biomass and consumption of sufficient water by transpiration associated with severe stress in relation to the normal condition (Tables 1 and 2 ). Furthermore, several scientific reports noted that plants with Si applied led to increased stomatal conductance (Figure 2B), transpiration rate (Figure 2C), and water content of leaf (Table 1), root and whole-plant hydraulic conductance $[2,62,63]$. Similar findings were found in various crop plants under stressed conditions [64-66].

Leaf water level is assessed by water uptake and transport, as well as transpirational loss [50]. The up-regulation in leaf water content and water capacity in the treatment with Si with the limited water supply was caused by the leaves' thickness as compared to the normal plants without Si [67]. Based on the recent findings, the responses of Si on transpiration rate may be associated to the plant species or varieties and atmospheric circumstances [50]; therefore, after the amendment with certain Si concentrations, an enhanced transpiration rate (Figure 2C; [44]) was observed in some plants, but reduced transpiration in some plants [68], and no change in others [43]. However, the exogenous 
use of $\mathrm{Si}$ was found to improve the photosynthetic capacity in various plants against limited water supply $[2,47,48]$.

An enhanced synthesis of osmolyte compounds, i.e., proline, has been associated with cellular membrane protection $[69,70]$. Furthermore, proline accumulation has also been related to an improvement of cellular water status and ROS scavenging in sugarcane crop [71,72]. It is widely reported that $\mathrm{Si}$ improved and/or maintained the plant tolerance to water deficit by adjusting osmolytes concentration in various crop plants [46,47].

Silicon has been reported to protect the damage of membrane caused by the formation of MDA [73] by regulating antioxidant defense in plants [46]. In present work, it has also been shown to reduce MDA content (Figure 3D), the end-product of lipid peroxidation in stressed plants [50,74-76], and thus may help to maintain/balance membrane integrity and reduce membrane permeability [26].

One of the immediate effects on plants subjected to water stress is the production of ROS, i.e., singlet oxygen, superoxide anion, $\mathrm{H}_{2} \mathrm{O}_{2}$ and hydroxyl radicals. The production and accumulation of ROS in the plants result in the severe destruction of the cellular ultrastructure, organelles and functions. The developed complex antioxidant system to balance and/or maintain homeostasis through enzymatic and non-enzymatic antioxidants is one of the strategies of the plants to mitigate and repair the damages caused by ROS $[2,3,77,78]$. The plants cultivated during stress suffer from water shortages, resulting in the overproduction of ROS in the plants [2,79]. By modulating the plant antioxidant defense systems, Si could also mitigate oxidative damage in plants subjected to water deficit conditions [11,77]. The treatment of water stressed plants with Si causing enhanced activities of CAT, POD and SOD enzymes was observed (Figure 3A,C,E), as in similar findings noticed by various researchers $[46,77,78,80]$. However, how Si mediates this response is still unclear. Under water stress, Si's effect on antioxidant enzymes in plants varies not only among plant species/cultivars, but also at various growth phases of the same plant [81]. Abiotic stresses like water deficit can also modify the antioxidant enzyme activities [82]. Overall, based on the presented results and available database, it could be concluded that $\mathrm{Si}$ may mitigate the oxidative damage in plants by modulating antioxidant defense system $[24,46,77,78]$.

The correlation coefficient ( $r$ ) for each set of parameters with silicon was found in the range of 0.178-0.999 (Supplementary Table S2). This means that the derived model verified the variations in photosynthetic and biochemical parameters against limited water irrigation levels with silicon almost 99.9\%. Model hypothesis explains for rate of variations in their percent increase in the observed parameters upon subjecting sugarcane to limited water supply with or without silicon application. This may be the direct proportion to the escalating silicon concentrations for predicting the gains in other crops in similar situations, which can also be verified.

The results of this study indicated that Si mitigated the detrimental effects of water stress on sugarcane. The addition of $\mathrm{Si}$ is a practical approach to maintain and/or increase environmental stresses [77]. Similar reports have shown that $\mathrm{Si}$ addition alleviates abiotic stresses, such as water and salt stresses, by up-regulating the activities of antioxidants enzymes $[2,73,79,80]$. Therefore, the induced enhancements in antioxidants status can be considered as an important mechanism or functions in the cellular defense strategy against abiotic stresses $[55,83,84]$. Silicon can not only maintain or improve the water deficit-tolerance of high accumulation rate of Si in plants (Figure 3F), but also upgrade the low Si-accumulating plants [50]. In this study, the stress-tolerant mechanism of the sugarcane plant on morpho-physiological and biochemical bases have been elucidated, which is consistent with the study aims.

In this study, it was evident that the uptake of $\mathrm{Si}$ was enhanced by increasing the application level of exogenous $\mathrm{CaO} \cdot \mathrm{SiO}_{2}$, while it was inhibited by decreasing soil moisture, suggesting Si may be involved in the metabolic and physiological capacity in sugarcane plants against water stress. Low soil moisture is one of the serious environmental circumstances limiting the growth and production of crop plants. Predictions of future climate might change to an enhanced severity and duration of stress in the era of climate change. Silicon, as a biologically active element, might be associated 
with physiological metabolism and/or structural formation when subjected to environmental stresses. The findings suggest that the application of $\mathrm{Si}$ to drought-exposed sugarcane crops would lead to better plant development and yield production under stressed conditions. It is therefore clear that part of the beneficial effects of $\mathrm{Si}$ on plants is linked to direct/indirect effects on the cell wall. In addition, the amendment of $\mathrm{Si}$ and its responses against in vivo conditions still needs extensive assessment. The role and/or functions of silicon in genomics and proteome of the sugarcane plants against limited water supply will be studied further in the future.

Supplementary Materials: The following are available online at http://www.mdpi.com/2223-7747/9/8/1032/s1, Figure S1: Outline indicates the days of plants period of the whole experiment, Table S1: Soil properties in the stusy, Table S2: Model parameters of morpho-physiological and antioxidant enzymes in responsive to different soil moisture levels with silicon.

Author Contributions: Conceptualization, K.K.V. and Y.-R.L.; methodology and data curation, K.K.V.; resources and software, K.K.V., M.A., Z.C., M.K.M., R.K.S. and P.S.; validation, C.L.V., writing-original draft preparation, K.K.V. and V.D.R., writing-review and editing, C.L.V., X.-P.S. and Y.-R.L.; supervision, X.-P.S. and Y.-R.L.; project administration and funding acquisition, Y.-R.L. All authors have read and agreed to the published version of the manuscript.

Funding: This study was supported by the Guangxi R and D Program Fund (GK17195100), Fund for Guangxi Innovation Teams of Modern Agriculture Technology (gjnytxgxcxtd-03-01), and Fund of Guangxi Academy of Agricultural Sciences (2015YT02).

Acknowledgments: We are sincerely thankful to the Guangxi Academy of Agricultural Sciences, Nanning, Guangxi, China for providing the necessary facilities for this study.

Conflicts of Interest: The authors declare there are no competing interests.

\section{References}

1. Chen, D.; Wang, S.; Yin, L.; Deng, X. How does silicon mediate plant water uptake and loss under water deficiency? Front. Plant Sci. 2018, 9, 281. [CrossRef]

2. Verma, K.K.; Liu, X.H.; Wu, K.C.; Singh, R.K.; Song, Q.Q.; Malviya, M.K.; Song, X.P.; Singh, P.; Verma, C.L.; Li, Y.R. The impact of silicon on photosynthetic and biochemical responses of sugarcane under different soil moisture levels. Silicon 2019. [CrossRef]

3. Vilela, R.D.; Bezerra, B.K.L.; Froehlich, A.; Endres, L. Antioxidant system is essential to increase drought tolerance of sugarcane. Ann. Appl. Biol. 2017, 171, 451-463. [CrossRef]

4. Glick, B.R. Bacteria with ACC deaminase can promote plant growth and help to feed the world. Microbiol. Res. 2014, 169, 30-39. [CrossRef]

5. Etesami, H.; Jeong, B.R. Silicon (Si): Review and future prospects on the action mechanisms in alleviating biotic and abiotic stresses in plants. Ecotoxicol. Environ. Saf. 2018, 147, 881-896. [CrossRef] [PubMed]

6. United Nations. World Population Prospects: Highlights. 2019. Available online: https://www.un.org/ development/desa/publications/world-population-prospects-2019highlights.html (accessed on 30 March 2020).

7. Sahebi, M.; Hanafi, M.M.; Akmar, A.S.N.; Rafii, M.Y.; Azizi, P.; Tengoua, F.F.; Azwa, J.N.M.; Shabanimofrad, M. Importance of silicon and mechanisms of biosilica formation in plants. BioMed Res. Int. 2015, 2015, 1-16. [CrossRef] [PubMed]

8. Meena, K.K.; Sorty, A.M.; Bitla, U.M.; Choudhary, K.; Gupta, P.; Pareek, A.; Singh, D.P.; Prabha, R.; Sahu, P.K.; Gupta, V.K. Abiotic stress responses and microbe mediated mitigation in plants: The Omics strategies. Front. Plant Sci. 2017, 8, 172. [CrossRef]

9. Rasool, S.; Hameed, A.; Azooz, M.; Siddiqi, T.; Ahmad, P. Salt Stress: Causes, Types and Responses of Plants. In Ecophysiology and Responses of Plants under Salt Stress; Springer: Berlin/Heidelberg, Germany, 2013; pp. 1-24.

10. Bodner, G.; Nakhforoosh, A.; Kaul, H.P. Management of crop water under drought: A review. Agron. Sustain. Dev. 2015, 35, 401-442. [CrossRef]

11. Verma, K.K.; Singh, R.K.; Song, Q.Q.; Singh, P.; Zhang, B.Q.; Song, X.P.; Chen, G.L.; Li, Y.R. Silicon alleviates drought stress of sugarcane plants by improving antioxidant responses. Biomed. J. Sci. Tech. Res. 2019, 17, 002957. 
12. Verma, K.K.; Wu, K.-C.; Singh, P.; Malviya, M.K.; Singh, R.K.; Song, X.-P.; Li, Y.R. The protective role of silicon in sugarcane under water stress: Photosynthesis and antioxidant enzymes. Biomed. J. Sci. Tech. Res. 2019, 15, 002685.

13. Mahajan, S.; Tuteja, N. Cold, salinity and drought stresses: An overview. Arch. Biochem. Biophys. 2005, 444, 139-158. [CrossRef] [PubMed]

14. Verslues, P.E.; Agarwal, M.; Katiyar-Agarwal, S.; Zhu, J.; Zhu, J.K. Methods and concepts in quantifying resistance to drought, salt and freezing, abiotic stresses that affect plant water status. Plant J. 2006, 45, 523-539. [CrossRef] [PubMed]

15. Aguiar, N.O.; Medici, L.O.; Olivares, F.L.; Dobbss, L.B.; Torres-Netto, A.; Silva, S.F.; Canellas, L.P. Metabolic profile and antioxidant responses during drought stress recovery in sugarcane treated with humic acids and endophytic diazotrophic bacteria. Ann. Appl. Biol. 2016, 168, 203-213. [CrossRef]

16. Bassi, B.; Menossi, M.; Mattiello, L. Nitrogen supply influences photosynthesis establishment along the sugarcane leaf. Sci. Rep. 2018, 8, 2327. [CrossRef] [PubMed]

17. Dias, M.O.S.; Cunhaa, M.P.; Jesusa, C.D.F.; Rochaa, G.J.M.; Pradellaa, J.G.C.; Rossella, C.E.V.; Filhoab, R.M.; Bonomia, A. Second generation ethanol in Brazil: Can it compete with electricity production? Bioresour. Technol. 2011, 102, 8964-8971. [CrossRef] [PubMed]

18. Pereira, S.C.; Maehara, L.; Machado, C.M.M.; Farinas, C.S. 2G ethanol from the whole sugarcane lignocellulosic biomass. Biotechnol. Biofuels 2015, 8, 44. [CrossRef]

19. Ma, J.F. Role of silicon in enhancing the resistance of plants to biotic and abiotic stresses. Soil Sci. Plant Nutr. 2004, 50, 11-18. [CrossRef]

20. Coskun, D.; Deshmukh, R.; Sonah, H.; Menzies, J.G.; Reynolds, O.; Ma, J.F.; Kronzucker, H.J.; Belanger, R.R. The controversies of silicon's role in plants biology. New Phytol. 2019, 221, 67-85. [CrossRef]

21. Griffin, M.; Hogan, B.; Schmidt, O. Silicon reduces slug feeding on wheat seedlings. J. Pest Sci. 2015, 88, 17-24. [CrossRef]

22. Rodrigues, F.A.; Dallagnol, L.J.; Duarte, H.S.S.; Datnoff, L.E. Silicon Control of Foliar Diseases in Monocots and Dicots. In Silicon and Plant Diseases; Rodrigues, F.A., Datnoff, L.E., Eds.; Springer: Cham, The Netherlands, 2015; pp. 67-108.

23. Reynolds, O.L.; Padula, M.P.; Zeng, R.; Gurr, G.M. Silicon: Potential to promote direct and indirect effects on plant defense against arthropod pests in agriculture. Front. Plant Sci. 2016, 7, 744. [CrossRef]

24. Frew, A.; Weston, L.A.; Reynolds, O.L.; Gurr, G.M. The role of silicon in plant biology: A paradigm shift in research approach. Ann. Bot. 2018, 121, 1265-1273. [CrossRef] [PubMed]

25. Epstein, E.; Bloom, A.J. Mineral Nutrition of Plants: Principles and Perspectives, 2nd ed.; Sinauer Associates: Sunderland, UK, 2005.

26. Liang, Y.; Nikolic, M.; Belanger, R.; Gong, H.; Song, A. Effect of silicon on crop growth, yield and quality. In Silicon in agriculture: From Theory to Practice; Liang, Y., Nikolic, M., Belanger, R., Gong, H., Song, A., Eds.; Springer: Dordrecht, The Netherlands, 2015; pp. 209-233.

27. Epstein, E. Silicon: Its manifold roles in plants. Ann. Appl. Biol. 2009, 155, 155-160. [CrossRef]

28. Ma, J.F.; Yamaji, N.; Mitani, N. Transport of silicon from roots to panicles in plants. Proc. Jpn. Acad. Ser. B Phys. Biol. Sci. 2011, 87, 377-385. [CrossRef] [PubMed]

29. Yamasaki, S.; Dillenburg, L.C. Measurements of leaf relative water content in Araucaria angustifolia. Rev. Brasilian Fisiol. Veg. 1999, 11, 69-75.

30. Hiscox, J.D.; Israelstam, G.F. A method for the extraction of chlorophyll from leaf tissue without maceration. Can. J. Bot. 1979, 57, 1332-1334. [CrossRef]

31. Sairam, R.K.; Deshmukh, P.S.; Shukla, D.S. Tolerance of drought and temperature stress in relation to increased antioxidant enzyme activity in wheat. J. Agron. Crop. Sci. 1997, 178, 171-178. [CrossRef]

32. Azevedo, M.M.; Carvalho, A.; Pascoal, C.; Rodrigues, F.; Caassio, F. Responses of antioxidant defenses to Cu and Zn stress in two aquatic fungi. Sci. Total. Environ. 2007, 377, 233-243. [CrossRef]

33. Bai, L.; Sui, F.; Ge, T.; Sun, Z.; Lu, Y.; Zhou, G. Effect of soil drought stress on leaf water status, membrane permeability and enzymatic antioxidant system of maize. Pedosphere 2006, 16, 326-332. [CrossRef]

34. Esposito, J.B.; Esposito, B.P.; Azevedo, R.A.; Cruz, L.S.; da Silva, L.C.; de Souza, S.R. Protective effect of Mn (III)-desferrioxamine B upon oxidative stress caused by ozone and acid rain in the Brazilian soybean cultivar Glycine max 'Sambaiba'. Environ. Sci. Pollut. Res. Int. 2015, 22, 5315-5324. [CrossRef] 
35. Bates, L.S.; Waldren, R.P.; Teare, I.D. Rapid determination of free proline for water stress studies. Plant Soil 1973, 39, 205-207. [CrossRef]

36. Bailly, C.; Benamar, A.; Corbineau, F.; Come, D. Changes in malondialdehyde content and in superoxide dismutase, catalase and glutathione reductase activities in sunflower seeds as related to deterioration during accelerated aging. Physiol. Plant. 1996, 97, 104-110. [CrossRef]

37. Wang, L.; Huang, X.; Zhou, Q. Effects of rare earth elements on the distribution of mineral elements and heavy metals in horseradish. Chemosphere 2008, 73, 314-319. [CrossRef] [PubMed]

38. Munns, R.; Tester, M. Mechanisms of salinity tolerance. Annu. Rev. Plant Biol. 2008, 59, 651-681. [CrossRef] [PubMed]

39. Gupta, B.; Huang, B. Mechanism of salinity tolerance in plants: Physiological, biochemical, and molecular characterization. Int. J. Genom. 2014, 2014, 701596. [CrossRef]

40. Ahmed, M.; Fayyaz-Ul-Hassen; Khurshid, Y. Does silicon and irrigation have impact on drought tolerance mechanism of sorghum? Agric. Water Manag. 2011, 98, 1808-1812. [CrossRef]

41. Hameed, A.; Sheikh, M.A.; Jamil, A.; Basra, S.M.A. Seed priming with sodium silicate enhances seed germination and seedling growth in wheat (Triticum aestivum L.) under water deficit stress induced by polyethylene glycol. Pak. J. Life Soc. Sci. 2013, 11, 19-24.

42. Hattori, T.; Inanaga, S.; Tanimoto, E.; Lux, A.; Luxova, M.; Sugimoto, Y. Silicon-induced changes in viscoelastic properties of sorghum root cell walls. Plant Cell Physiol. 2003, 44, 743-749. [CrossRef]

43. Hattori, T.; Sonobe, K.; Inanaga, S.; An, P.; Morita, S. Effects of silicon on photosynthesis of young cucumber seedlings under osmotic tress. J. Plant Nut. 2008, 31, 1046-1058. [CrossRef]

44. Chen, W.; Yao, X.; Cai, K.; Chen, J. Silicon alleviates drought stress of rice plants by improving plant water status, photosynthesis and mineral nutrient absorption. Biol. Trace Element Res. 2011, 142, 67-76. [CrossRef]

45. Farooq, M.; Wahid, A.; Kobayashi, N.; Fujita, D.; Basra, S. Plant drought stress: Effects, mechanisms and management. Agron. Sustain. Dev. 2009, 29, 185-212. [CrossRef]

46. Zhu, Y.; Gong, H. Beneficial effects of silicon on salt and drought tolerance in plants. Agron. Sustain. Dev. 2019, 34, 455-472. [CrossRef]

47. Rizwan, M.; Ali, S.; Ibrahim, M.; Farid, M.; Adrees, M.; Bharwana, S.A.; Zia-ur-Rehman, M.; Qayyum, M.F.; Abbas, F. Mechanisms of silicon-mediated alleviation of drought and salt stress in plants: A review. Environ. Sci. Pollut. Res. 2015, 22, 15416-15431. [CrossRef] [PubMed]

48. Gong, H.J.; Chen, K.M. The regulatory role of silicon on water relations, photosynthetic gas exchange, and carboxylation activities of wheat leaves in field drought conditions. Acta Physiol. Plant. 2012, 34, 1589-1594. [CrossRef]

49. Karmollachaab, A.; Bakhshandeh, A.; Gharineh, M.; Moradi Telavat, M.; Fathi, G. Effect of silicon application on physiological characteristics and grain yield of wheat under drought stress condition. Int. J. Agro. Plant Prod. 2013, 4, 30-37.

50. Shi, Y.; Zhang, Y.; Han, W.; Feng, R.; Hu, Y.; Guo, J.; Gong, H. Silicon enhances water stress tolerance by improving root hydraulic conductance in Solanum lycopersicum L. Front. Plant Sci. 2016, 7, 196. [CrossRef] [PubMed]

51. Tahir, M.; Ahmed, S.; Ayub, M.; Naeem, M.; Sarwar, M. Impact of planting time and silicon levels on yield and yield components of sunflower (Helianthus annuus L.). Pak. J. Life Soc. Sci. 2013, 11, 60-64.

52. Amin, M.; Ahmad, R.; Ali, A.; Hussain, I.; Mahmood, R.; Aslam, M.; Lee, D.J. Influence of silicon fertilization on maize performance under limited water supply. Silicon 2016, 10, 177-183. [CrossRef]

53. Yahdjian, L.; Sala, O.E. Vegetation structure constrains primary production response to water availability in the Patagonian Steppe. Ecology 2006, 87, 952-962. [CrossRef]

54. Hu, L.; Wang, Z.; Huang, B. Diffusion limitations and metabolic factors associated with inhibition and recovery of photosynthesis from drought stress in a $C_{3}$ perennial grass species. Physiol. Plant. 2010, 139, 93-106. [CrossRef]

55. Zhang, X.; Du, Y.; Wang, L.; Zhou, Q.; Huang, X.; Sun, Z. Combined effects of lanthanum (III) and acid rain on antioxidant enzyme system in soybean roots. PLoS ONE 2015, 10, e0134546. [CrossRef]

56. Hossain, M.T.; Mori, R.; Soga, K.; Wakabayashi, K.; Kamisaka, S.; Fujii, S.; Yamamoto, R.; Hoson, T. Growth promotion and an increase in cell wall extensibility by silicon in rice and some other Poaceae seedlings. J. Plant Res. 2002, 115, 23-27. [CrossRef] [PubMed] 
57. Akram, H.M.; Sattar, A.; Ali, A.; Nadeem, M.A. Agro-physiological performance of wheat genotypes under moisture stress conditions. J. Agric. Res. 2010, 48, 361-368.

58. Sabater, B.; Rodriquez, M.I. Control of chlorophyll degradation indetached leaves of barley and oat through effect of kinetin on chlorophyllase levels. Physiol. Plant. 1978, 43, 274-276. [CrossRef]

59. Gong, H.J.; Zhu, X.Y.; Chen, K.M.; Wang, S.M.; Zhang, C.L. Silicon alleviates oxidative damage of wheat plants in pots under drought. Plant Sci. 2005, 169, 313-321. [CrossRef]

60. Ruiz-Espinoza, F.H.; Murillo-Amador, B.; Garcia-Hernandez, J.L.; Fenech-Larios, L.; Rueda-Puente, E.O.; Troyo-Dieguez, E.; Kaya, C.; Beltran-Morales, A. Field evaluation of the relationship between chlorophyll content in basil leaves and a portable chlorophyll meter (SPAD-502) readings. J. Plant Nut. 2010, 33, 423-438. [CrossRef]

61. Cornic, G. Drought stress inhibits photosynthesis by decreasing stomatal aperture-not by affecting ATP synthesis. Trends Plant Sci. 2000, 5, 187-188. [CrossRef]

62. Yin, L.N.; Wang, S.W.; Li, J.Y.; Tanaka, K.; Oka, M. Application of silicon improves salt tolerance through ameliorating osmotic and ionic stresses in the seedling of Sorghum bicolor. Acta Physiol. Plant. 2013, 35, 3099-3107. [CrossRef]

63. Liu, H.; Sultan, M.A.; Liu, X.L.; Zhang, J.; Yu, F.; Zhao, H.X. Physiological and comparative proteomic analysis reveals different drought responses in roots and leaves of drought tolerant wild wheat (Triticum boeoticum). PLoS ONE 2015, 10, e0121852. [CrossRef]

64. Sairam, R.K. Effect of moisture stress on physiological activities of two contrasting wheat genotypes. Ind. J. Exp. Biol. 1994, 32, 584-593.

65. Rajput, V.D.; Chen, Y.; Ayup, M. Effects of high salinity on physiological and anatomical indices in the early stages of Populus euphratica growth. Russ. J. Plant Physiol. 2015, 62, 229-236. [CrossRef]

66. Li, C.; Nong, Q.; Solanki, M.K.; Liang, Q.; Xie, J.; Liu, X.; Li, Y.; Wang, W.; Yang, L.; Li, Y. Differential expression profiles and pathways of genes in sugarcane leaf at elongation stage in response to drought stress. Sci. Rep. 2016, 6, 25698. [CrossRef] [PubMed]

67. Gong, H.J.; Chen, K.M.; Chen, G.C.; Wang, S.M.; Zhang, C.L. Effects of silicon on growth of wheat under drought. J. Plant Nutr. 2003, 26, 1055-1063. [CrossRef]

68. Gao, X.; Zou, C.; Wang, L.; Zhang, F. Silicon decreases transpiration rate and conductance from stomata of maize plants. J. Plant Nutr. 2006, 29, 1637-1647. [CrossRef]

69. Ashraf, M.; Foolad, M.R. Roles of glycine betaine and proline in improving plant abiotic stress resistance. Environ. Exp. Bot. 2007, 59, 206-216. [CrossRef]

70. Cia, M.C.; Guimaraes, A.C.R.; Medici, L.O.; Chabregas, S.M.; Azevedo, R.A. Antioxidant responses to water deficit by drought-tolerant and sensitive sugarcane varieties. Ann. Appl. Biol. 2012, 161, 313-324. [CrossRef]

71. Molinari, H.B.C.; Marur, C.J.; Daros, E.; Campos, M.K.F.; Carvalho, J.F.R.P.; Bespalhok Filho, J.C.; Pereira, L.F.P.; Vieira, L.G.E. Evaluation of the stress-inducible production of proline in transgenic sugarcane (Saccharum spp.): Osmotic adjustment, chlorophyll fluorescence and antioxidative stress. Physiol. Plant. 2007, 130, 218-225. [CrossRef]

72. Wahid, A.; Close, T.J. Expression of dehydrins under heat stress and their relationship with water relations of sugarcane leaves. Biol. Plant. 2007, 51, 104-109. [CrossRef]

73. Zhu, Z.; Wei, G.; Li, J.; Qian, Q.; Yu, J. Silicon alleviates salt stress and increases antioxidant enzymes activity in leaves of salt-stressed cucumber (Cucumis sativus L.). Plant Sci. 2004, 167, 527-533. [CrossRef]

74. Liang, Y.; Chen, Q.I.N.; Liu, Q.; Zhang, W.; Ding, R. Exogenous silicon (Si) increases antioxidant enzyme activity and reduces lipid peroxidation in roots of salt stressed barley (Hordium vulgare L.). Plant Physiol. 2003, 160, 1157-1164. [CrossRef]

75. Moussa, H.R. Influence of exogenous application of silicon on physiological response of salt-stressed maize (Zea mays L.). Int. J. Agric. Biol. 2006, 8, 293-297.

76. Soylemezoglu, G.; Demir, K.; Inal, A.; Gunes, A. Effect of silicon on antioxidant and stomatal response of two grapevine (Vitis vinifera L.) rootstocks grown in boron toxic, saline and boron toxic-saline soil. Sci. Hortic. 2009, 123, 240-246. [CrossRef]

77. Kim, Y.H.; Khan, A.L.; Waqas, M.; Lee, I.J. Silicon regulates antioxidant activities of crop plants under abiotic-induced oxidative stress: A review. Front. Plant Sci. 2017, 8, 510. [CrossRef] [PubMed]

78. Verma, K.K.; Singh, P.; Song, X.P.; Malviya, M.K.; Singh, R.K.; Chen, G.L.; Solomon, S.; Li, Y.R. Mitigating climatic change for sugarcane improvement: Role of silicon in alleviating abiotic stresses. Sugar Tech. 2020. [CrossRef] 
79. Liang, Y. Effects of silicon on enzyme activity, and sodium, potassium and calcium concentration in barley under salt stress. Plant Soil 1999, 209, 217-224. [CrossRef]

80. Ju, S.; Yin, N.; Wang, L.; Zhang, C.; Wang, Y. Effects of silicon on Oryza sativa L. seedling roots under simulated acid rain stress. PLoS ONE 2017, 12, e0173378. [CrossRef] [PubMed]

81. Gong, H.J.; Chen, K.M.; Zhao, Z.G.; Chen, G.C.; Zhou, W.J. Effects of silicon on defense of wheat against oxidative stress under drought at different developmental stages. Biol. Plant 2008, 52, 592-596. [CrossRef]

82. Demidchik, V. Reactive Oxygen Species and Oxidative Stress in Plants. In Plant Stress Physiology; CAB International: Oxford, UK, 2012; pp. 24-58.

83. Gunes, A.; Inal, A.; Bagci, E.G.; Pilbeam, D.J. Silicon-mediated changes of some physiological and enzymatic parameters symptomatic for oxidative stress in spinach and tomato grown in sodic-B toxic soil. Plant Soil 2007, 290, 103-114. [CrossRef]

84. Peng, Q.; Zhou, Q. Antioxidant capacity of flavonoid in soybean seedlings under the joint actions of rare earth element la (III) and ultraviolet-B stress. Biol. Trace Element Res. 2009, 127, 69-80. [CrossRef]

(C) 2020 by the authors. Licensee MDPI, Basel, Switzerland. This article is an open access article distributed under the terms and conditions of the Creative Commons Attribution (CC BY) license (http://creativecommons.org/licenses/by/4.0/). 